\title{
Examining effective factors on human forces' productivity in bureau of naval operations
}

\author{
Younes Bahadori*
}

Department of Management, Dehaghan Branch, Islamic Azad University, Isfahan, Iran

\section{H R O N I C L E}

\begin{tabular}{l}
\hline Article history: \\
Received September 18, 2014 \\
Accepted 17 December 2014 \\
Available online \\
December 182014 \\
\hline Keywords: \\
Human forces \\
Productivity \\
Employees training \\
Meritocracy system
\end{tabular}

\section{Introduction}

Organizations are a set of human, technological, technical, structural, cultural factors and other environmental elements that are interacting in line with fulfilling a set of predetermined and common objectives. Undoubtedly, with regard to that, these goals and people's interests do not necessarily have conformity and the way managers confront in establishing balance, reducing conflict and optimal using potential abilities in people and elements is important. In this regard, employees in each organization are considered the most important components that ignoring their demands and not providing their

*Corresponding author.

E-mail addresses: bahadori.younes2011@gmail.com (Y. Bahadori)

(c) 2015 Growing Science Ltd. All rights reserved.

doi: $10.5267 /$ j.ms 1.2014 .12 .013 \begin{abstract}
A B S T R A C T
This research aims at examining effective factors on improvement of human forces' productive and determining degree of influence and importance of each group among factors supervision on employees, degree of employees training, occupational value of employees and at last, administrating meritocracy system on improvement of human forces' productivity. Statistical population is composed of bureau of naval operations' employees in oil terminals' company in Khark, Iran. Statistical population has been 230, among which 135 people were determined as statistical sample size using Cochran formula. Survey instrument in this research has been questionnaire, according to which employees' ideas about effective factors on employees' productivity were evaluated. These questionnaires completed by people among statistical sample contain 16 close questions which were set up according to Likert 5 -grade scale and were distributed as 135 numbers that after returning questionnaire, statistical analysis and data processing were accomplished. Analysis was performed in 2 descriptive and inferential statistics levels. Results of data analysis show that: A) 5-fold factors under review "workshop equipment and arrangement of organization, system of control and supervision on employees, degree of employees training, occupational value of employees and administrating meritocracy related to human resources by management" have had effects on improvement of employees' productivity as average. B) degree of employees training and then occupational value of employees and administrating meritocracy system have had the most influence, and workshop equipment and arrangement of organization and system of control and supervision on employees have had the least influence.
\end{abstract}

C 2015 Growing Science Ltd. All rights reserved. 
needs are not compensatory. A set of scientific achievements shows that, from the simplest accessories to the most advanced complicated technologies, there have been products of creativity and innovation of scientists which have been established based on human knowledge and mental evolution in many years. So, the original base of wealth in any countries is to build on human resource that is the main factor, and material and natural resources are considered consequential factors. In such circumstances, the role of human resource has been extended not only in organizational level but as a whole from one small economic unit to national level. In addition to cultural factor, technological, social, political and economic factors play essential role for business improvement. Factors constituting external environment and governing situations into the organization beside people's maturity and insight on the other hand are also important. Moreover, awareness and manager's insights influence on productivity. (Kutan \& Yigit, 2007). If productivity is regarded as the culture of optimal and suitable utilization of existing equipment, it is obvious that we are all responsible for these God's blessings. The need to productivity is obvious not only by national but in terms of personal perspective. First step to do everything is to establish a suitable work environment for higher productivity and better ways. We can daringly claim that productivity is the only parameter in which all effective factors in an organization are influencing and this may reduce productivity in the organization. The necessity for productivity on economic, social and cultural progress has been recommended for years, but this is just in recent years that targeted and planned efforts have been beginning for systematic increasing productivity by productivity management (Grönroos \& Ojasalo, 2004).

\section{Theoretical basics}

\subsection{The history of productivity}

Productivity is a concept in economy and management that is defined as the amount of produced products and services in terms of each unit of energy and/ or cost work without reduction in quality, or as: effectiveness in addition to performance. In other words, productivity is to reach the maximum probable profit with optimum exploiting and using work force, capability, talent and skill in human force, land, car, money, equipment, time, place, etc. in order to improve welfare society. Productivity is defined as accomplished work ratio to the work which should be executed. Note that the word "productivity" was extended in industrial revolution and in order for increase in profit from workforce, invest and factors like these (Vasileiadou \& Vliegenthart, 2009).

\subsubsection{Productivity from systematic perspective}

Each system design has its own algorithm. So, on measuring productivity, a set of data is regarded as input that after doing a set of process, it turns into final (output) product. So, on measuring productivity we confront with a system to achieve optimum productivity $(\mathrm{Oz}, 2005)$.

\subsubsection{Productivity from Japanese perspective}

KoheeGooshi, founder of Japanese Productivity Center, on the greeting cards which he sends for friends, writes: "productivity is a goal which is achievable by continuous improving material equipment and human forces". This simple but meaningful sentence is the most obvious definition indicating the reality of productivity, because in productivity, human' spiritual and mental improvement is paid attention as much as materials and equipment. In addition, several experiences indicate that the newest engineering and managerial techniques and findings are effective only when work environment is so suitable that employees could afford in line with management in order to increase the productivity while becoming compatible and matching with these techniques. So, it is obvious that the first step to increase productivity is to arrest cooperation and workers' support from efforts accomplished for this purpose. So, before companies choose the best slogan to increase productivity, it is necessary for workers to support this issue while being complete familiar with productivity because productivity has mutual benefits for them 


\subsubsection{Productivity levels}

Productivity contains different levels. Learning productivity has been introduced from personal to the universal levels, which could be addressed below.

1. Personal productivity

Personal productivity is optimum using from a set of person's potential talents and skills in the course of self-life progress. Training, learning and human force development and people participation in running the organization increase in organization's productivity in addition to personal productivity improvement.

\section{Productivity at home}

Productivity evolution at home leads to decrease in waste, waste elimination and a better life quality in using life grace.

\section{Productivity at organization}

Productivity improvement in an organization has been the result of optimum and effective and efficient using from resources, reduction in waste, cost price reduction, quality improvement, rising clients' satisfaction, desirability in work place and increase in employees' motivation and favorite about the better work that at last will lead to organization development.

\section{Productivity in national level}

Productivity increase is the only way of economic development of countries that causes improvement in a nation life welfare level. Miraculous evolution in fast economic growth and development in some countries.

\section{Green productivity}

Until a few decades ago, natural environment was not introduced as an important variable in producing systems, but gradually, environmental damages endangered achievements of human civilization. Waste and producing effluents have led to the environmental pollution. Devastation left from excessive using from ecosystems and damage to the natural resource especially nonrenewable resource leading to more concerns and forced human to find a way to prevent from these undesirable consequences

\subsubsection{Barriers to productivity improvement}

- Not having national belief and faith to results and benefits of productivity improvement,

- Fear from some outer appearance of productivity such as fear from unemployment,

- Public unawareness about concepts and status of productivity, degree of its importance and people' role and duty in this respect,

- Ignoring innovative and creative thoughts,

- Not paying attention to management, economy and accounting courses,

- People resistance against changes and not tending to leave some habits,

- Drowning in ways and techniques and thought beliefs changes,

- Ambition and ignoring apparently small problems and small solutions,

- Not specifying business trustee,

- Mismatch and lack of suitable guidance and supervision,

- Weakness in administrative commitment,

- Rush in acquiring result,

- Unwarranted interference by some experts in other work areas and non-expert comments,

- Not availability of skilled experts or their lack of motivation in evaluating system and analysis and measuring productivity, 
- Sectional encounter with productivity's issue and discontinuity in process of productivity (Jin et al., 2012).

\subsubsection{Factors influencing on productivity}

Looking at successful countries in the world, we can observe that these countries pay necessary attention to the human force as producing factor and against it, they are shared in profits resulted from production by raising self-productivity, that raising productivity leads to establishment of a system from which all social categories use.

\section{Factors influencing on productivity from "Nakayama" perspective}

"Nakayama" believes that factors influencing on productivity are from 2 types: (A) short term factors and (B) long term factors. Short term changes in productivity often depend on degree of personnel motivation for work and improvement of current ways and systems and work flow and changes in degree of work pressure and current fluctuation (Fernandes, 2007). Long term factors influencing on productivity include establishing and developing new products, introducing new producing ways, exploring new resources and finding new channels for marketing (Fernandes, 2007).

\section{Factors influencing on productivity from "International Labor Organization" perspective}

International labor organization has categorized factors influencing on productivity from a broader perspective into 3 following groups:

- Total factors such as weather, geographical distribution, raw materials, etc.,

- Organizational and technical factors such as raw materials quality, localizing and carrying and establishing factory, erosion and destroying machinery and instruments, etc.,

- Human factors such as the relationship between management and employees, social and mental situation of work, trade union, etc. (Halpern et al., 2006).

\section{Factors influencing on productivity in America from Gangopadhyay's perspective}

Gangopadhyay et al. (2006) states several factors se factors influencing on productivity such as rate of investment, combining work force, factory and equipment life, investor ratio, work ethics, management, research and development, rate of utilization from capacity, workers' concern about losing job, energy costs, government laws and unions effects.

\subsection{Native model of factors influencing on productivity of human force in Iran}

\section{System of control and supervision on employees}

Acquiring competitive advantage in industrial and producing organizations depends on various standards associated with goods and services.

Management and supervision of staff and human resources development have to be accomplished, systematically. Developing job career, allocation of resources, evaluation and feedback and also fair reminding job problems and direct or indirect supervision to personnel may help organizations achieve desired level of developments.

\section{Improvement of personnel's training level}

Today, acquiring competitive advantage depends on educating and managing human forces in an organization. Knowledge-based organizations may be established and developed by producing knowledge. When members of organization are educated in their jobs, they do their work in desired way, which leads to organizational success. Theoretical trainings accompanied with practical training and consequently having necessary skills and required skill for a job and also short term training in order for qualitative improvement of organization play an important role for business improvement. 
3. Maintaining employees' occupational value

Partial value of an occupation is a portion which occupation contains in order for fulfilling organization. Accountability, skill, effort and job situation contribute occupational value. One aspect of employees' satisfaction is to consider job situation, personality aspects and their mental needs. In organizations, members' dignity and status should be much more considered so that satisfaction and being valuable feeling revive in them. Members' spiritual encouragement is also a way that enforces relation among members and organization, and person enjoys his job, and it is a factor for more motivation on innovative administrating affairs (Kutan \& Yigit, 2007).

\section{Administrating meritocracy system}

In fulfillment of meritocracy system and setting policies and decisions related to the human resource, meritocracy pattern as goals should be defined as a process as far as possible in organization strategies and, and its mechanism should be defined and measured by obvious and simple words. Granting post and responsibility to people should be considered by their ability and merit level, and there should be adopted a way from which evaluating employees match with their real merit and giving value to competent and merit people that cause others motivation is considered.

\subsection{Research theoretical framework}

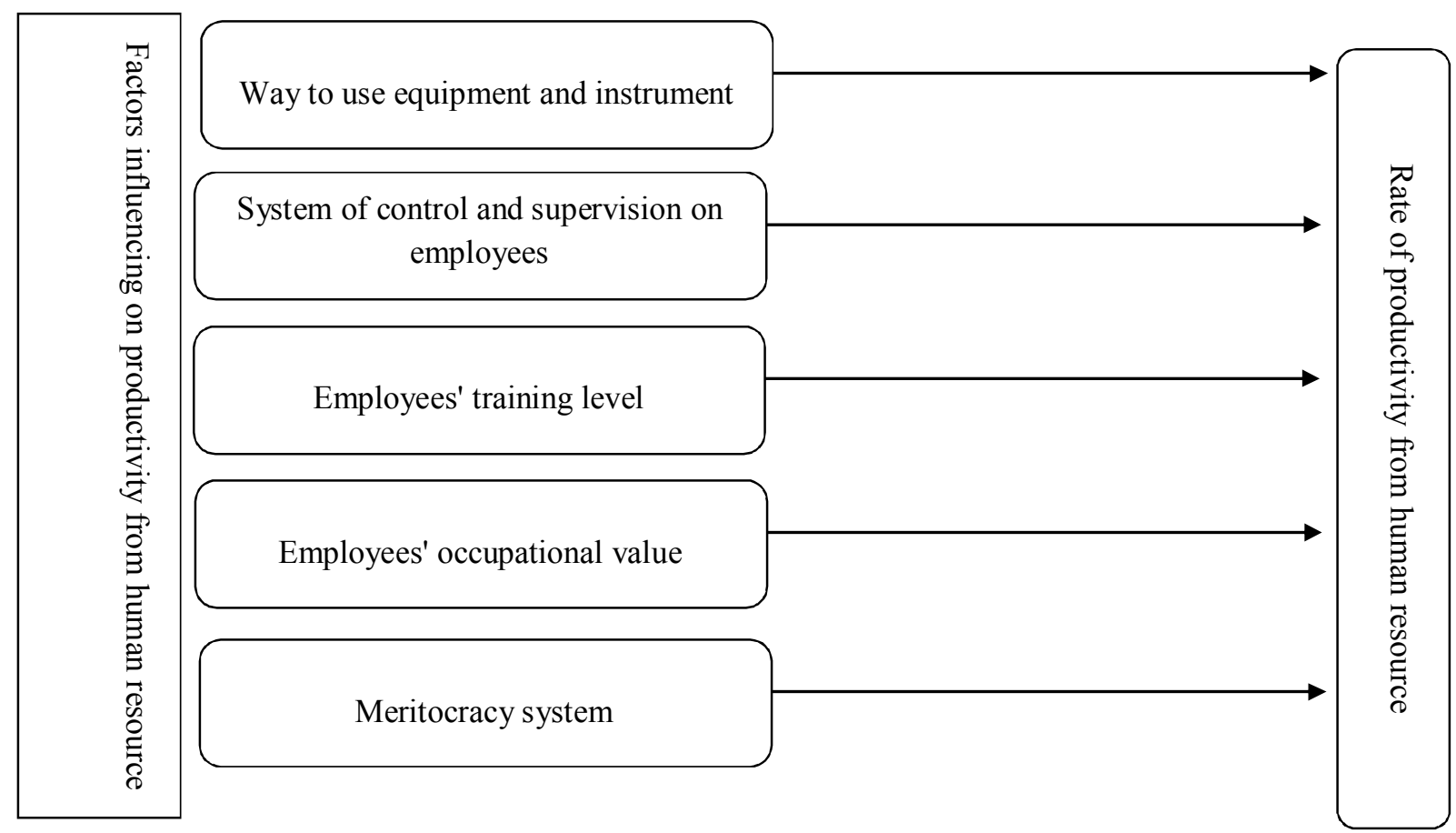

Fig. 1. A native model from factors influencing on productivity from human resource in Iran

\subsection{Research hypothesis}

1. There is a significant relationship between the way to use organization equipment and instrument and productivity from human resource.

2. There is a significant relationship between system of control and supervision on employees and productivity from human resource.

3. There is a significant relationship between employees' training level and productivity from human resource.

4. There is a significant relationship between employees' occupational value and productivity from human resource.

5. There is a significant relationship between meritocracy system and productivity from human resource. 


\section{Research method}

Current research is descriptive-survey and correlation- based by collecting data. It is descriptive by this respect that findings are described as collected and without manipulation and the relationships between variables have been examined and the relationship between dependent variable and dependent variables are evaluated. Since information has been acquired by a random sample from original population by questionnaire, survey aspect in this examination has been provided, too.

\section{Statistical population, sample size and sampling method}

Statistical population in this research contains all 330 employees of corporate and staff units in bureau of naval operations in oil terminals' company located in Khark, Iran. Choice of personnel population from corporate and staff units has been executed by guidance from supervisor, and with regard to complete familiarity of these units' employees with productivity concepts, and on the other hand, depending on raising knowledge and scientific education level in this population and in order for research population restriction in line with more precise conclusion about research subject they were chosen as research statistical population. Sample size was determined by using Cochran formula as 135. For sampling from considered population, random sampling method proportional to sample size has been used.

\section{Instrument of collecting data}

In this research, researcher- made questionnaire "factors influencing on productivity from human force" is used. Population or sample members helped us by filling questionnaire and returning it to researcher. For this reason, questions and guidance related should be so obvious and understandable that respondents can respond to questions easily. In this research, Likert graded scale has been used for preparing and setting questionnaire. Total numbers of questions are 17, 16 of which organize general questions and next question organizes writing people ideas (if they want). The way of scoring to questions being from very low to very high is from 1 to 5 . With regard to calculated sample, 135 questionnaires were distributed among statistical population that after collecting questionnaires, we did statistical analysis and data processing. Validity of each questionnaire was verified by experts' idea. For making sure about reliability of questionnaires, Cronbach Alpha method was used that reliability coefficient of questionnaire was obtained as 0.82 .

\section{Data analysis method}

Analyzing collected data in this research was done in 2 descriptive and inferential levels. In descriptive level, analyzing data was accomplished using statistical features like frequency, frequency percent, mean, and in inferential level, Pearson correlation coefficient $\mathrm{R}$ was used in proportional to data evaluation level and statistical tests hypothesis.

\section{Research variables normality test}

$H_{0}=$ data are normally distributed. $\quad H_{1}=$ data are not normally distributed.

Table 1

Results from research variables normality test (Kolmogorov-Smirnov)

\begin{tabular}{lcl}
\hline Variable & Sig. & Test result \\
\hline Way to use organization's equipment and instrument & 0.872 & Data distribution is normal \\
System of control and supervision on employees & 0.743 & Data distribution is normal \\
Employees' training level & 0.921 & Data distribution is normal \\
Employees' occupational value & 0.832 & Data distribution is normal \\
Meritocracy system & 0.941 & Data distribution is normal \\
Rate of productivity from human resource & 0.753 & Data distribution is normal \\
\hline
\end{tabular}

According to Table 1, significance level (Sig) in research variables normality test is more than 0.05. So, hypothesis $H_{0}$ is proved, that is, data distribution in this statistical sample is normal. For this reason, Pearson's parametric tests are used to test research hypothesis. 


\section{Research findings}

First hypothesis: There is a significant relationship between the way to use organization's equipment and instrument and productivity from human force.

$H_{0}$ : There is not a significant relationship between the way to useorganization's equipment and instrument and productivity from human force.

$H_{1}$ : There is a significant relationship between the way to use organization's equipment and instrument and productivity from human force.

\section{Table 2}

Results from Pearson's test about relationship between the way to use organization's equipment and instrument and productivity from human resource

\begin{tabular}{lcc}
\hline Index & $\begin{array}{c}\text { Way to use organization's } \\
\text { equipment and instrument }\end{array}$ & $\begin{array}{c}\text { Productivity from } \\
\text { human resource }\end{array}$ \\
\hline $\begin{array}{l}\text { Way to use organization's equipment and instrument } \\
\text { (Pearson Correlation) }\end{array}$ & 1 & $-0.1^{* *}$ \\
Significance level (2-tailed) & & 0.24 \\
Sample size (N) & 135 & 135 \\
Productivity from human force (Pearson Correlation) & $-0.1^{* *}$ & 1 \\
Significance level (2-tailed) & 0.24 & 135 \\
Sample size (N) & 135 & 135 \\
\hline
\end{tabular}

** Correlation is significant at the 0.05 level (2-tailed)

As we can observe from the results of Table 2, obtained correlation level between the way to use organization's equipment and instrument and productivity from human force is $(r=-0.1)$, that it is not significant at level 0.95 ( $\mathrm{sig}=0.24$ ), so, there is not a significant relationship between the way to use organization's equipment and instrument and productivity from human force in bureau of naval operations in oil terminals company on Khark, and first hypothesis is not proved at error level $(\alpha=$ $0.05)$.

Second hypothesis: There is a significant relationship between system of control and supervision on employees and productivity from human force.

$H_{0}$ : There is not a significant relationship between system of control and supervision on employees and productivity from human force.

$H_{1}$ : There is a significant relationship between system of control and supervision on employees and productivity from human force.

\section{Table 3}

Result from Pearson's test about relationship between system of control and supervision on employees and productivity from human resource

\begin{tabular}{lcc}
\multicolumn{1}{c}{ Index } & $\begin{array}{c}\text { System of control and supervision } \\
\text { on employees }\end{array}$ & $\begin{array}{c}\text { Productivity from human } \\
\text { resource }\end{array}$ \\
\hline $\begin{array}{l}\text { System of control and supervision on } \\
\text { employees (Pearson Correlation) }\end{array}$ & 1 & $0.08^{* *}$ \\
Significance level (2-tailed) & & 0.32 \\
Sample size (N) & 135 & 135 \\
$\begin{array}{l}\text { Productivity from human force (Pearson } \\
\text { Correlation) }\end{array}$ & $0.08^{* *}$ & 1 \\
Significance level (2-tailed) & 0.32 & 135 \\
Sample size (N) & 135 & \\
\hline
\end{tabular}

** Correlation is significant at the 0.05 level (2-tailed)

As we can observe from the results of Table 3, obtained correlation level between system of control and supervision on employees and productivity from human force is $(\mathrm{r}=0.08)$, that it is not significant 
at level of 0.95 ( $\mathrm{sig}=0.32)$, so, there is not a significant relationship between system of control and supervision on employees and productivity from human force in bureau of naval operations in oil terminals company on Khark and second hypothesis is not proved at error level $(\alpha=0.05)$.

Third hypothesis: There is a significant relationship between employees' training level and productivity from human force.

$H_{0}$ : There is not a significant relationship between employees' training level and productivity from human force.

$H_{1}$ : There is a significant relationship between employees' training level and productivity from human force.

Table 4

Result from Pearson's test about relationship between employees' training level and productivity from human resource

\begin{tabular}{lcc}
\hline Index & Employees' training level & Productivity from human resource \\
\hline $\begin{array}{l}\text { Employees' training level (Pearson } \\
\text { Correlation) }\end{array}$ & 1 & $0.48^{* *}$ \\
Significance level (2-tailed) & & 0.04 \\
Sample size (N) & 135 & 135 \\
Productivity from human force & $0.48^{* *}$ & 1 \\
(Pearson Correlation) & & 135 \\
Significance level (2-tailed) & 0.04 & 135 \\
Sample size (N) & 135 & \\
\hline
\end{tabular}

** Correlation is significant at the 0.05 level (2-tailed)

As we can see from the results of Table 4, obtained correlation level between employees' training level and productivity from human force is $(\mathrm{r}=0.48)$, that it is not significant at level $0.95(\mathrm{sig}=0.04)$, so, there is a significant relationship between employees' training level and productivity from human force in bureau of naval operations in oil terminals company on Khark and third hypothesis is proved at error level $(\alpha=0.05)$.

Forth hypothesis: There is a significant relationship between employees' occupational value and productivity from human force.

$H_{0}$ : There is not a significant relationship between employees' occupational value and productivity from human force.

$H_{1}$ : There is a significant relationship between employees' occupational value and productivity from human force.

Table 5

Result from Pearson's test about relationship between employees' occupational value and productivity from human resource

\begin{tabular}{ccc}
\hline Index & Employees' occupational value & Productivity from human resource \\
\hline $\begin{array}{c}\text { Employees' occupational value (Pearson } \\
\text { Correlation) }\end{array}$ & 1 & $0.46^{* *}$ \\
Significance level (2-tailed) & & 0.03 \\
$\quad$ Sample size (N) & 135 & 135 \\
Productivity from human force (Pearson \\
$\quad$ Correlation) & $0.46^{* *}$ & 1 \\
Significance level (2-tailed) & 0.03 & 135 \\
Sample size (N) & 135 & \\
\hline
\end{tabular}

${ }^{* *}$ Correlation is significant at the 0.05 level (2-tailed)

As we can see from the results of Table 5, obtained correlation level between employees' occupational value and productivity from human force is $(\mathrm{r}=0.46)$, that it is significant at level $0.95(\mathrm{sig}=0.03)$, so, there is a significant relationship between employees' occupational value and productivity from human 
force in bureau of naval operations in oil terminals company on Khark and forth hypothesis is proved at error level $(\alpha=0.05)$.

Fifth hypothesis: There is a significant relationship between meritocracy system and productivity from human force.

$H_{0}$ : There is not a significant relationship between meritocracy system and productivity from human force.

$H_{1}$ : There is a significant relationship between meritocracy system and productivity from human force.

\section{Table 6}

Result from Pearson's test about relationship between meritocracy system and productivity from human resource

\begin{tabular}{lcc}
\hline Index & Meritocracy system & Productivity from human resource \\
\hline Meritocracy system (Pearson Correlation) & 1 & $0.37^{* *}$ \\
Significance level (2-tailed) & & 0.01 \\
Sample size (N) & 135 & 135 \\
Productivity from human force (Pearson Correlation) & $0.37^{* *}$ & 1 \\
Significance level (2-tailed) & 0.01 & 135 \\
Sample size (N) & 135 & \\
\hline
\end{tabular}

** Correlation is significant at the 0.05 level (2-tailed)

As we can observe from the results of Table 6, obtained correlation level between meritocracy system and productivity from human force is $(\mathrm{r}=0.37)$, that it is significant at the level of $0.95(\mathrm{sig}=0.01)$, so, there is a significant relationship between meritocracy system and productivity from human force in bureau of naval operations in oil terminals company on Khark and fifth hypothesis is proved at error level $(\alpha=0.05)$.

\section{Conclusion and Recommendation}

Results have indicated that employees believed that respectively, raising training level, respecting occupational value and administrating meritocracy system were the most important factors influencing on their productivity. Therefore, we may make the following recommendation for productivity improvement.

\subsection{Improvement of training level}

On employees' belief, improvement of training level which contains short term trainings or theoretical trainings accompanied by practical trainings and subsequently having necessary skills and required skills for job is regarded as the most important factor on improvement of employees' productivity. So, it is recommended that a new and more effective insight is adopted in setting educational policies and administrating educational programs consistent with person's specialty so that people can participate in educational terms freely and actively and also by establishing motivation in people participate in educational terms spontaneously and eagerly. Also, it is recommended that in order for qualitative improvement on education, especially on international periods (terms), experienced professors from other countries who are familiar with modern techniques and technology associated to marine and maritime are utilized.

\subsection{Maintaining employees' occupational value}

According to employees' view, employees' occupational value that is indeed considering people' status and indignity should be paid more attention by people in charge and management in bureau of naval operations, and truly this "economic mission" hard burden of oil terminals' company on Khark. So, it is recommended that in setting organizational policies, arrangements are to be considered so that all working forces in this bureau enjoy better occupational value for employing forces active and creative and interested in naval industry in other bureau. Also, decisions are made based on establishing a unit in staff as examining operational forces affairs including administrative, educational, and welfare- 
based work so that it could provide protection and support from human resources. In this way, we can decline people's conflicts which are frequently observed in organizations especially governmental offices. To remove feeling loneliness and worthlessness and incuriosity among employees, always efforts should be done in order to grow forces creative, motivated and loyal to organizational goals that finally influence on productivity improvement. It is also recommended that managers and people in charge in organizations, with regard to situation and equipment, try to recognize employees' needs, and by encouraging them, provide diverse fields to increase employees' motivation.

\subsection{Appropriate implementing meritocracy system}

Results show that employees believe that appropriate implementing meritocracy system including evaluating employees upon their real competence and also granting a post and accountability to people according to employees' ability and competence and sometimes valuing elite and competent people for implementing meritocracy system are regarded as factors influencing on employees' productivity improvement. Therefore, it is recommended that in setting policies and decisions based on human resources, meritocracy model is defined as a goal possibly in organizational strategy and as a process, its mechanism is defined and measured by obvious and simple words, time table for implementing steps is designed, and human resources' and organizational behavior's experts and counselors are helped. Also, necessary arrangements should be considered and for making organizational decisions, managers should consider principle "meritocracy" and laws and rules and norms governing employees' population with regard to pragmatic index. Sometimes, avoiding unreasonable and undocumented decisions and providing a regular and valid system on making decision especially in granting a post to people and evaluating employees increase reliability of decisions related to the human resources.

\section{References}

Chang, T. P., Hu, J. L., Chou, R. Y., \& Sun, L. (2012). The sources of bank productivity growth in China during 2002-2009: A disaggregation view. Journal of Banking \& Finance, 36(7), 1997-2006.

Oz, E. (2005). Information technology productivity: in search of a definite observation. Information \& Management, 42(6), 789-798.

Fernandes, A. M. (2007). Trade policy, trade volumes and plant-level productivity in Colombian manufacturing industries. Journal of international economics, 71(1), 52-71.

Gangopadhyay, S., Das, T., Ghoshal, G., \& Ghosh, T. (2006). Work organization in sand core manufacturing for health and productivity. International Journal of Industrial Ergonomics, 36(10), 915-920.

Grönroos, C., \& Ojasalo, K. (2004). Service productivity: towards a conceptualization of the transformation of inputs into economic results in services. Journal of Business Research, 57(4), 414423.

Halpern, L., Koren, M., \& Szeidl, A. (2006). Imports and Productivity. Federal Reserve Bank of New York, Mimeo, New York.

Javorcik, B. S. (2004). Does foreign direct investment increase the productivity of domestic firms? In search of spillovers through backward linkages. American economic review, 94, 605-627.

Jin, Q., Overend, M., \& Thompson, P. (2012). Towards productivity indicators for performance-based façade design in commercial buildings. Building and Environment, 57, 271-281.

Kutan, A. M., \& Yigit, T. M. (2007). European integration, productivity growth and real convergence. European Economic Review, 51(6), 1370-1395.

Motohashi, K. (2007). Firm-level analysis of information network use and productivity in Japan. Journal of the Japanese and International Economies, 21(1), 121-137.

Tang, K., Beaton, D. E., Lacaille, D., Gignac, M. A., \& Bombardier, C. (2013). Sensibility of five atwork productivity measures was endorsed by patients with osteoarthritis or rheumatoid arthritis. Journal of clinical epidemiology, 66(5), 546-556.

Vasileiadou, E., \& Vliegenthart, R. (2009). Research productivity in the era of the internet revisited. Research Policy, 38(8), 1260-1268. 